\title{
Trote violento contra calouros universitários
}

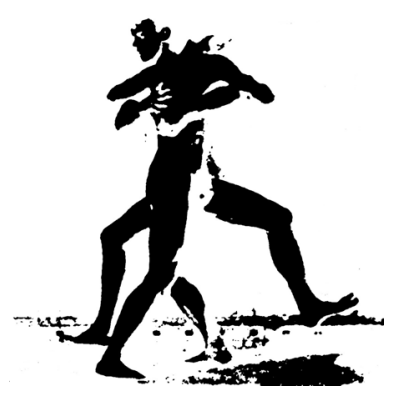

Marco Segre

Notícias de trote violento contra calouros universitários têm sido comuns, desde sempre. Vez ou outra há vítimas fatais e o "trote" passa, então, a ser discutido pela imprensa. Formam-se comissões de sindicância nas faculdades, chamam-se psicólogos, bacharéis e cientistas sociais para opinarem sobre o "fenômeno"...

Há bastante hipocrisia nisso tudo, porque há décadas se sabe o que é o trote $e$ as reações do público sempre variaram da sorridente cumplicidade com esse "baile de debutantes", à tolerância enfastiada e até à inaceitação mais severa.

Como encarar o fato? (falo do fato em si, independentemente de surgirem vítimas fatais).

Trata-se, indiscutivelmente, de uma violência. A consideração de que se trata de um "ritual" que faz parte da tradição acadêmica deste e de alguns outros países não altera esse aspecto. A amputação do clitóris em certos grupos islâmicos, as práticas de emancipação de adolescentes em tribos indígenas, as humilhações impostas aos recrutas do exército são outros exemplos em que a justificativa do "cultural" poderá também ser levantada. Mas, por esse caminho, também justificaríamos a lavagem étnica de Kosovo ou até mesmo as câmeras de gás de Auschwitz.

\footnotetext{
${ }^{1}$ Médico, professor de Bioética da Faculdade de Medicina da Universidade de São Paulo - FMUSP. Membro do Conselho Regional de Medicina do Estado de São Paulo.
} 


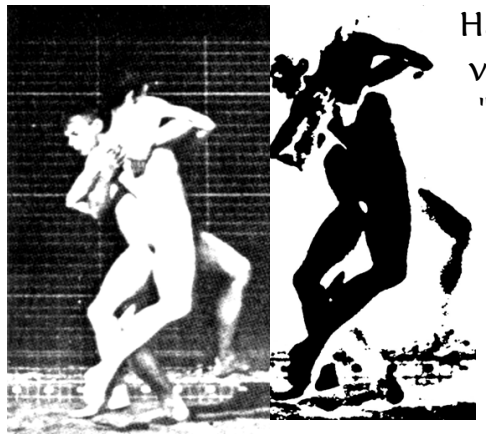

Há, sim, violências que são até prazeirosas para suas vítimas. Sem recorrermos ao exemplo do ótimo filme "O império dos sentidos" - em que o estrangulamento progressivo era estímulo erótico para dois amantes o prazer de ser submetido à dor ou a humilhações por seus pares (é o caso de todos os rituais de iniciação) advém do orgulho de ser admitido numa "casta superior". E quanto mais pessoas virem, maior será esse prazer.

Não estamos aqui, porém, para discutir o prazer ou desprazer que o trote pode causar em uns e outros. Eu mesmo, por ocasião de minha entrada na FMUSP, não odiei o trote. Houve algo de festivo, para mim, na participação solidária, com antigos e novos companheiros, nessa "maratona" que se sucedeu à minha auspiciosa entrada na Faculdade. Cresci. Aprendi a perceber "algo mais" na postura de muitos (não todos) "veteranos" que "dão o trote". Há sentimentos de vingança contra o que muitos deles sequer atinam. Há prazer na submissão de indefesos, no "tudo posso", há revanchismo no "eu passei por isso e agora é a vez deles" (talvez seja por isso que, não me tendo sentido vilipendiado pelo trote, não tive o desejo de retribuí-lo). Mas também não é para avaliarmos todos os aspectos emocionais que permeiam o trote que escrevo este artigo.

Virei professor de Bioética. Embora eu não atribua à "autonomia, beneficência, não maleficência e justiça", o sentido que os principialistas the querem dar (linha de Beauchamps e Childress), pois fujo de tudo o que seja normativo em termos de "pensar e sentir humanos", é claro que, na maioria das vezes, o trote é uma violação da autonomia. O fato de muitos acabarem gostando (ou, até mesmo, de já iniciarem gostando) lembra-me o adágio de "se você for estuprada, relaxa e goza". Sorte de quem pode. É absolutamente certo, também, que qualidade de vida é subjetividade. Que se faça uma consulta, antes do trote, para saber quem o deseja. E que se especifiquem, como num contrato, as condições em que ele será aplicado. $E$ que se obtenha a anuência, por escrito, dos "sujeitos". Afinal, serão essas mesmas pessoas que, ao cabo de um curso de Medicina, deverão saber que, tanto para o exercício profissional como para a pesquisa em seres humanos, exige-se o consentimento esclarecido! Não será fácil, para os professores de Bioética, transmitir para esses alunos (ex-calouros e ex-veteranos) o valor do respeito à autonomia após todas suas vivências no trote e fora dele.

Estamos quase na virada do milênio. Expande-se o fundamentalismo religioso, muitos se escondem atrás do cientificismo e do determinismo (o gene explica tudo, para que teríamos, então, que pensar e decidir?). Não obstante isso, fala-se bastante em respeito aos valores humanos, à individualidade, à etnia e à opção sexual. Com quem estamos, no embate entre essas duas tendências? Não tenho qualquer dúvida de que o verdadeiro desafio da virada do milênio passa pelo humanismo.

E este, certamente, não passa pelo trote, nem pela cumplicidade a todo tipo de violência. Também não passa pela gabolice irresponsável e insensível de atribuir a si mesmo um homicídio que, até, não se haja praticado! 